\title{
Journalism and the Islamic Worldview
}

Journalistic roles in Muslim-majority countries

\section{Nurhaya Muchtar, Basyouni Ibrahim Hamada, Thomas Hanitzsch, Ashraf Galal, Masduki \& Mohammad Sahid Ullah}

To cite this article: Nurhaya Muchtar, Basyouni Ibrahim Hamada, Thomas Hanitzsch, Ashraf Galal, Masduki \& Mohammad Sahid Ullah (2017) Journalism and the Islamic Worldview, Journalism Studies, 18:5, 555-575, DOI: 10.1080/1461670X.2017.1279029

To link to this article: https://doi.org/10.1080/1461670X.2017.1279029

\section{曲 Published online: 02 Feb 2017.}

Submit your article to this journal $\pi$
LII Article views: 950

Q View related articles

View Crossmark data $₫$

Citing articles: 8 View citing articles \ulcorner 


\title{
JOURNALISM AND ISLAMIC WORLDVIEW Journalistic roles in Muslim-majority countries
}

\author{
Nurhaya Muchtar, Basyouni Ibrahim Hamada, \\ Thomas Hanitzsch, with Ashraf Galal, Masduki, and \\ Mohammad Sahid Ullah
}

\begin{abstract}
This paper looks at the extent to which journalistic culture in Muslim-majority countries is shaped by a distinctive Islamic worldview. We identified four principles of an Islamic perspective to journalism: truth and truth-telling (siddiq and haqq), pedagogy (tabligh), seeking the best for the public interest (maslahah), and moderation (wasatiyyah). A survey of working journalists in Africa (Egypt, Sierra Leone, and Sudan), Asia (Bangladesh, Indonesia, Malaysia, Oman, Qatar, Turkey, and the United Arab Emirates), and Europe (Albania and Kosovo) found manifestations of these roles in the investigated countries. The results point to the strong importance of an interventionist approach to journalism-as embodied in the maslahah principle-in most societies. Overall, however, journalists' roles in Muslim-majority countries are not so much shaped by a distinctively Islamic worldview as they were by the political, economic, and socio-cultural contexts.
\end{abstract}

KEYWORDS Islam; Islamic culture; Islamic view of journalistic roles; Muslim-majority countries; universal journalistic roles; Worlds of Journalism Study

\section{Introduction}

In the past two decades, a variety of studies have examined the relationship between Islam, Islamic culture, and several aspects of journalism. These studies often emphasized normative issues (Azzi 2011; Hamada 2016) as well as general characteristics of journalism, such as press freedom, media laws, media policy, and media ownership (Amin 2002; Hamada 2004, 2008; Hamdy 2013; Sakr 2006), as well as self-censorship and restrictions in the newsroom (Hamayotsu 2013). Furthermore, recent years have seen a considerable stream of comparative analyses, for example by Hafez (2002), Steele (2011, 2013), and Pintak (2014; Pintak and Ginges 2008; Pintak and Setiyono 2011; Pintak and Nazir 2013).

In many Muslim-majority countries, governments tend to institutionalize journalists' roles to their own advantage, often expressed in the form of a country's national "philosophy," such as Indonesia's Pancasila doctrine, which tends to lead to self-censorship among journalists (Connolly-Ahern and Golan 2007; Hamayotsu 2013) or Rukun Negara in Malaysia, which emphasizes moral behavior and loyalty to the King (Kaur 2000).

Furthermore, religious institutions and the society they live in can also restrict journalists' work. As a result, journalists often make an effort to meet public expectations by emphasizing news stories that have a positive value for society and humanity (Steele 2013). While this is certainly part of journalists' job, reporting only news stories that are considered "good" stories inevitably displaces other stories that are relevant to the public's needs.

The present study moves beyond previous studies by looking at a larger set of countries and regions, focusing on the professional roles as perceived by journalists in 
12 Muslim-majority countries. This study is an attempt to explore how journalists from Africa (Egypt, Sierra Leone, and Sudan), South and Southeast Asia (Bangladesh, Indonesia, and Malaysia), West Asia (Oman, Qatar, Turkey, and United Arab Emirates (UAE)), and Europe (Albania and Kosovo) reflect on the role journalism plays in their societies. This article, therefore, is addressing the following research questions:

RQ1: To what extents do journalists in the investigated countries have similar understandings of journalism's role in society?

RQ2: Do journalists in these countries share certain professional views that may lend themselves to the idea of an "Islamic journalism"?

For the purpose of this analysis, we selected all Muslim-majority countries that reported data for the Worlds of Journalism Study. The 12 countries differ in terms of their political system, economic development, and with regards to culture and traditional heritage. Islam and Islamic culture in these societies have historically blended with indigenous custom and tradition in often distinctive ways. This variation provides a unique opportunity to examine differences among journalists' perceptions of their roles in a predominantly Islamic environment.

\section{Journalistic Roles in the Literature}

Following Hanitzsch and Vos (2017), we suggest studying journalistic roles from within the perspective of discursive institutionalism (Schmidt 2010). In the tradition of looking at journalism as discursive practice (Carlson 2015; Zelizer 1993), we understand journalistic roles as discursively constituted reality. In order to be intelligible, they exist as part of a wider framework of meaning-of a discourse. At the core of this discourse is journalism's identity and locus in society (Hanitzsch and Vos 2017). The discourse sets the parameters of what is desirable in a given institutional context; it legitimizes and delegitimizes certain norms, ideas, and practices. Here, journalistic roles perform a double duty -they act as a source of institutional legitimacy relative to the broader society and, through a process of socialization, they inform the cognitive toolkit that journalists use to think about their work. In a discursive perspective, journalistic roles are never static; they are subject to discursive (re)creation, (re)interpretation, appropriation, and contestation.

From a conceptual point of view, there are two distinct sets of roles: normative and cognitive roles. Normative roles are external to individual journalists; they encompass generalized and aggregate expectations that journalists believe are deemed desirable in society (Donsbach 2012). Being confronted with the realities on the ground, normative roles are subject to discursive reproduction and conservation, as well as to contestation and struggle. Cognitive roles, on the other hand, can be seen as the institutional values, attitudes, and beliefs individual journalists embrace as a result of their socialization. Appearing mostly as evident, natural, and self-explaining to the journalists (Schultz 2007), cognitive roles capture their individual aspirations and ambitions, and the communicative goals they want to achieve through their work.

Journalistic roles have attracted researchers' attention since the early years of communication research. Cohen (1963) was one of the first to systematically study journalists' perception of their professional roles. His classification into "neutral" and "participant" roles 
was later taken further by Janowitz (1975), who identified the "gatekeeper" and the "advocate" as ideal-typical roles of American journalists. Weaver and Wilhoit (1996) popularized research on journalists' roles by distinguishing four sets of roles: the "disseminator," "interpreter," "adversarial," and "populist mobilizer." Notably, Weaver and Wilhoit's work has become a blueprint for a large number of studies outside the United States that largely followed their original questionnaire (see Weaver 1998; Weaver and Willnat 2012). The last two decades have seen an explosion of comparative research on journalistic roles. An early example is Donsbach and Patterson's (2004) survey of journalists in Germany, Italy, Sweden, the United Kingdom, and the United States. The largest comparative study of journalistic roles to date identified journalists' interventionism-that is, their willingness to actively involve themselves in social development-to be a main denominator of cross-national variation (Hanitzsch et al. 2011).

A growing number of studies specifically look at journalists' roles beyond the western world. In a series of surveys, Pintak (2014; Pintak and Nazir 2013), for instance, found journalists in the Arab and Islamic world to serve their audiences in the capacity of an agent of change. Other studies identified journalistic traits that correspond to the idea of "development journalism" in parts of Asia and Africa (Edeani 1993; Ramaprasad and Kelly 2003; Ramaprasad and Rahman 2006; Romano 2003). Steele (2013, 355), therefore, concluded that "although the principles and (roles) of journalism may indeed be universal, they are understood and expressed within particular political and cultural contexts." In many African contexts, for example, journalistic role models fall into three major domains: journalism for social change, communal journalism, and journalism based on oral discourse (Skjerdal 2012).

The need for alternative concepts that are better suited to the realities in the nonwestern world has long been recognized (e.g., Hachten 1981). Asian scholarship, for instance, has linked the media's role to the preservation of social harmony and respect for leadership, which urges journalists to restrain from coverage that could potentially disrupt social order (Masterton 2005; Xu 2005). The discomfort that many scholars in the global South felt with the uncritical adoption of western normative ideas was perhaps best articulated by Mehra $(1989,3)$, who argued that "unlike the individualistic, democratic, egalitarian and liberal tradition of Western political theory, some societies value their consensual and communal traditions with their emphasis on duties and obligations to the collective and social harmony."

\section{Journalistic Roles in Muslim-majority Countries}

The way journalists enact and articulate their roles in Muslim-majority countries is influenced by a variety of factors. Malaysia is known for revoking media licenses and imprisonment of critical journalists (Tapsell 2013). Turkey is a recent example for massive government intervention into the media system, in addition to the media exercising a substantive degree of political parallelism (Kaya and Çakmur 2010). In Sudan, the political regime utilizes the press as a tool for political mobilization of popular support, while implementing censorship and tight control over the media (Rugh 2014). In Qatar, freedom of expression is guaranteed by the country's constitution, but the government has reportedly paid for Al-Jazeera's operating costs since its inception (Valeriani 2010). Kosovo is a post-conflict society and still in a stage of transition toward democracy (Taylor 2015).

Throughout the Arab world, journalistic roles are strongly shaped by a public sense of patriotism, which has led to further restrictions of media practices. Governments 
introduced codes of ethics that require the news media to adhere to patriotic and particular moral values (Hafez 2002). Journalists, publishers, and other media practitioners in many of these countries continue to be victims of harassment and political pressures, including dismissal, censorship, restraints on travel, physical assault, threats, arrest, detention, torture, abduction, passport withdrawals, and exile (Amin 2002; Ayish 2010).

The conditions under which journalists work in these countries clearly influence the way they reflect on journalism's contribution to society. Pintak (2014; Pintak and Nazir 2013) found journalists in the Muslim world act as "agents of change" in their respective communities. Such a perception may be driven by the particular political situation in these countries as well as by socio-cultural values. In Indonesia, for instance, journalists are expected to act as promoters for socio-economic development and as protectors of "authentic" cultural values, such as an appreciation of spirituality and family values (Romano 2003). In Malaysia, the government enforces the media to promote national ideology and national unity (Kaur 2000). Similarly, a majority of journalists in Qatar perceived themselves as supporters of national unity and national development (Kirat 2016). The "collaborative role" identified in Egypt calls on journalists to actively provide discursive support and legitimacy to the political regime by publicizing governmental policies (EI Issawi and Cammaerts 2015).

\section{Journalism Principles and Islamic Perspective}

The influence of Islamic culture and heritage, however, has received surprisingly little scholarly attention, with a few exceptions (e.g., Ayish 2003; Ferjani 2010). The search for what one could call "Islamic journalism" somewhat fell through the cracks, which has most likely resulted from a dominance of western journalism textbooks and training. One question that drove the present analysis, therefore, was whether there is any such thing as a distinctively "Islamic journalism"—one that has traits and properties different from other journalistic cultures. Such a view may be less compelling to readers who may feel that religious belief may be of little relevance to the practice of journalism. Mowlana (1993), however, argues that while religion in the West is divorced from public life and social action is left to the conscience of the individual, this separation did not necessarily materialize in Islam, and if attempts were made by the late modernizers to do this, the process was never completed. Hence, in order to trace the potential foundation of a distinctive Islamic paradigm of journalistic roles, we need to extract some of the principles that may serve as its foundation.

An Islamic perspective on journalism can be meaningfully derived from the main sources of Islamic worldview, which include: the Qur'an and Sunnah, the Muslims' heritage, the human heritage, and reason and experience (Hamada 2016). Sunnah encompasses Islamic custom, the religious practices established by Prophet Muhammad among his companions, the textual forms of which are contained in the Qur'an and the Hadith (narrations of the Prophet's companions). Both the Qur'an and Sunnah encourage using reason and rationality as a basic means to protect us from untruth, inaccuracy, and evil doing. The following discourse between Prophet Muhammad and Muadh ibn Jabal emphasizes the importance of reasoning as one of the main sources of the Islamic worldview:

The Prophet: how will you decide on a problem?

Ibn Jabal: I will decide according to the Qur'an. 
The Prophet: If it is not in the Qur'an?

Ibn Jabal: according to the Sunnah.

Prophet: if it is not in that either?

Ibn Jabal: then I will use my own reasoning. (Ahmed 1992, 118)

Ramli (2005) introduced the idea of Prophetic Journalism, which is based on four positive attitudes from Prophet Muhammad, which include: always telling the truth (siddiq), having the ability to keep anonymity of their sources (amanah), and spreading truth and good deeds to the public (tabligh). In addition, journalists are expected to be smart and think critically based on an understanding that the journalists' job is to influence public opinion; hence, these roles need to be exercised carefully for the sake of developing society rather than simply reporting negative news. Furthermore, he emphasized two important dimensions in relation to Islam and journalism: building a better image of Islam, and making a positive contribution to the community. Pintak (2014) identified six additional concepts in his study of journalism in Indonesia, Malaysia, and Pakistan, which include the concepts of justice ('adl), telling the truth (haqq), independence (nasihah), ${ }^{1}$ balance (I'tidal), prevention of evil attitude (hisbah), and respecting and valuing moderation (wasatiyyah).

While all of those values are important to look at, this paper focuses on four basic principles of journalism as perceived by Islamic worldview. The first principle is the concept of haqq (truth). The Qur'an clearly instructs: "Do not mix haqq (truth) with batil (falsehood) and hide the haqq (truth) knowledgably" (92:42). In his research, Hamada (2016) counts at least 138 references to the root word naba-meaning "news" that must be based on truth unmixed with willful falsehood-in the Qur'an. The principle is essential, as indicated in the Qu'ran: "O Believers... verify it, lest you adversely impact some people unknowingly and then become embarrassed over what you did" (49:6). Furthermore, Hamada (2001) argues that the news must carry a strong sense of responsibility and accountability on the part of journalists and their organizations.

The second principle is based on set of concepts that cluster around a pedagogic function of journalists as public communicators, mostly known as tabligh, which broadly means to spread truth and good deeds to the public. In the context of this principle, journalists are expected to play the role of an educator, or teacher, who promotes a positive attitude to the members of the audience and encourages them to do good deeds. This principle is embodied in the concept of al-amr bil-ma'ruf wa-n-nahy 'an il-munkar, usually translated as "enjoining what is right and forbidding what is wrong." This key principle obliges Muslims to invite good and "forbid, whether in words, acts, or silent denunciation, any evil which they see being committed" (Kamali 1998, 28). This understanding can constitute a dilemma to journalists when it invites them to avoid telling the truth for a concern over fitnah (defamation). Thus, many journalists tend to disseminate only news stories that are good for society and humanity in order to avoid fitnah (Steele 2013). Such expectations and restrictions often resulted in increasing rates of self-censorship and further restriction in the newsroom (Hamayotsu 2013).

The third principle is called maslahah, which means to seek the best for the public interest. The idea behind this is perhaps best illustrated by one of Prophet Muhammad's sayings: "Whosoever of you sees an evil action, he must change it with his hand. If he is not able to do so, then with his tongue. If he is not able to do so then with his heart and this is the weakest of faith" (Muslim; Hadith 34). What this principle essentially calls 
for is a profoundly interventionist attitude and participant stance. Journalists are not seen as detached observers, as bystanders and uninvolved witnesses. To the contrary, journalists are expected to involve themselves in public discourse and to take a stance in order to promote social change in society. Journalists serve their audience in the role of an "agent of change" who contributes to the betterment of society (Pintak 2014).

The final principle is called wasatiyyah, which means "moderation," a concept emphasized in both the Qur'an and Sunnah (Ushama 2014). Moderation in this context implies impartiality and fairness; journalists may not endorse a particular political cause or support one side of the conflict over the other (Hamada 2016). The core meaning of moderation is justice (' $a d l)$. This notion carries a wide array of connotations, including straightness, straightforwardness, impartiality, fairness, equitableness, probity, honesty, uprightness, equitable composition or just composition. There are obvious tensions between the moderation principle and maslahah, if the latter is primarily understood in terms of an interventionist attitude.

If the above principles contribute to journalistic culture in Muslim-majority countries in substantive ways, then it makes sense to expect a certain degree of commonality between the 12 investigated countries. At the same time, however, the countries differ in many important respects (see Table 1). Muslims constitute the majority of the population in all 12 countries, but to a different degree. The share of Muslims of the overall population ranges between about 100 percent in Turkey and around 60 percent in Albania, Malaysia, and Sierra Leone. Within the Muslim majority in those countries, differences also exist with regards to the various denominations in Islam. Muslim populations are predominantly Sunni in all countries with the exception of Oman, which is dominated by orthodox lbadhism. Furthermore, journalists are operating in different political systems. Indonesia and Malaysia are democratic countries, while Oman, Qatar Sudan, and the UAE are classified as authoritarian regimes. Political and media freedom ranges between "partly free" and "not free" according to the Freedom House classification. Economic and human development is relatively high in the oil-exporting Gulf region, while it is low in Sierra Leone.

Finally, Islam also differs with regards to its connection to the state and social life. Albania, Bangladesh, Egypt, Indonesia, Kosovo, Malaysia, Sierra Leone, and Turkey are predominantly secular societies in which Islam often blends with ancient custom and tradition. Sudan and the three Gulf states, on the other hand, practice a much more orthodox version of Islam, where Islamic law (Shari'a) applies to most or all domains of public life.

\section{Method}

This comparative study is based on a cross-sectional survey of professional journalists in Albania, Bangladesh, Egypt, Indonesia, Kosovo, Malaysia, Oman, Qatar, Sierra Leone, Sudan, UAE, and Turkey. The data for this study were collected between 2012 and 2015, based on a collaborative effort of researchers from 66 countries who participated in the Worlds of Journalism Study. To recruit respondents, collaborators typically employed stratified (by rank) proportional random sampling. The data were obtained through face-toface, telephone, email, online and paper-and-pencil surveys, or a combination thereof. Response rates were generally very high, ranging between 68 percent in Qatar and 95 percent in Egypt and Malaysia. ${ }^{2}$

The questionnaire was initially created in English and was then translated into local languages where necessary. In order to answer our research questions, we presented to the 
TABLE 1

Countries included in the study

\begin{tabular}{|c|c|c|c|c|c|c|c|c|c|c|c|c|}
\hline & Albania & Bangladesh & Egypt & Indonesia & Kosovo & Malaysia & Oman & Qatar & $\begin{array}{l}\text { Sierra } \\
\text { Leone }\end{array}$ & Sudan & Turkey & UAE \\
\hline $\begin{array}{c}\text { Reference } \\
\text { year }^{\mathrm{a}}\end{array}$ & 2012 & 2013 & 2012 & 2015 & 2015 & 2014 & 2015 & 2013 & 2013 & 2014 & 2014 & 2014 \\
\hline $\begin{array}{l}\text { Political } \\
\text { regime }^{b}\end{array}$ & $\begin{array}{l}\text { Hybrid } \\
\text { regime }\end{array}$ & $\begin{array}{l}\text { Hybrid } \\
\text { regime }\end{array}$ & $\begin{array}{l}\text { Hybrid } \\
\text { regime }\end{array}$ & $\begin{array}{l}\text { Flawed } \\
\text { democracy }\end{array}$ & - & $\begin{array}{l}\text { Flawed } \\
\text { democracy }\end{array}$ & Authoritarian & Authoritarian & $\begin{array}{l}\text { Hybrid } \\
\text { regime }\end{array}$ & Authoritarian & $\begin{array}{l}\text { Hybrid } \\
\text { regime }\end{array}$ & Authoritarian \\
\hline $\begin{array}{l}\text { Political } \\
\text { freedom }^{c}\end{array}$ & Partly free & Partly free & Partly free & Partly free & $\begin{array}{l}\text { Partly } \\
\text { free }\end{array}$ & Partly free & Not free & Not free & Partly free & Not free & Partly free & Not free \\
\hline $\begin{array}{l}\text { Press } \\
\quad \text { Freedom }^{c} \\
\text { Economic }\end{array}$ & Partly free & Partly free & Not free & Partly free & $\begin{array}{l}\text { Partly } \\
\text { free }\end{array}$ & Not free & Not free & Not free & Partly free & Not free & Not free & Not free \\
\hline
\end{tabular}

aThe year when the survey was conducted (Worlds of Journalism Study).

${ }^{\mathrm{b}}$ Democracy Index (Economist Intelligence Unit).

${ }^{\mathrm{c}}$ Freedom House.

${ }^{\mathrm{d} E c o n o m i e s}$ by gross national income per capita (United Nations Department of Economic and Social Affairs).

dUnited Nations Development Programme.

${ }^{\mathrm{f}}$ Central Intelligence Agency World Factbook. 
journalists a number of statements related to different aspects of journalistic roles (see Table 3). The statements were preceded by following question: "Please tell me how important each of these things is in your work." Respondents were given five response options, ranging from "extremely important" (5) to "unimportant" (1).

Overall, more than 3500 journalists responded to the survey in the 12 countries. Table 2 presents some background information on the sample and basic characteristics of the interviewed journalists. Sample size varied between 662 respondents in Indonesia and 94 in Turkey. The maximum sampling error was smaller than 5 percent in all countries but Turkey. The percentage of women journalists varied considerably across the 12 countries; it was lowest in Bangladesh (10.9 percent) and highest in Malaysia (52.4 percent), Albania (51.7 percent), and the UAE (50.2 percent). Journalists were, on average, between 31 and 38 years old. Numbers did not differ greatly between the countries; journalists were youngest in Kosovo (31 years) and oldest in Oman (38 years). Likewise, journalists were on average least experienced in Sierra Leone (6 years) and Kosovo and Indonesia (8 years); they were most experienced in Oman (13 years). With the exception of Sierra Leone, the majority of journalists in all studied countries had a university degree; the percentage of those who specialized in journalism varied between 32 percent in Turkey and 73 percent in the UAE.

\section{Results}

Table 3 provides an overview of the journalists' responses in the investigated 12 countries. The table reports mean scores for the various aspects of journalistic roles along with their standard deviations and the percentages of respondents who found these roles to be "extremely" or "very important." We also conducted a set of one-way ANOVAs in order to get a sense of how different the journalists in the 12 countries were with regards to their role perceptions. The various roles in the table are ordered according to their relative importance, using the average mean across countries. The average standard deviations indicate the extent of disagreement within the countries (larger standard deviations point to higher disagreement). $\mathrm{Eta}^{2}$ values represent the amount of variation that is due to country differences; the higher the values the more countries differ on this role. It is worth noting that the measures used for the present article were based on the Worlds of Journalism Survey questionnaire, which was not specifically tailored to tap into a distinctively Islamic understanding of journalistic roles and culture.

In most of the studied Muslim-majority countries, journalists highly emphasized the ideas of reporting things "as they are" and acting as a detached observer (see Table 4). The representational role was almost unanimously supported across the sample, while the detached observer role was most appreciated in Albania and Kosovo, Egypt and Sudan, Oman and Qatar, and Turkey. Bangladesh somewhat escaped from this trend. Average standard deviations were relatively small, while country differences account for 15.3 and 19.5 percent of the variation in the journalists' responses. This suggests that journalists agreed on the importance of these roles with their colleagues in the same country, but there was some notable variation between different societies. Overall, however, this variation was a matter of degree rather than pointing to a qualitative difference. Seen from an Islamic perspective, the above two aspects of journalistic roles very much represent the principles of truth and truth-telling (siddiq and haqq) as well as moderation (wasatiyyah), the latter of which implying impartiality and fairness. Can we take such commonality for a distinctive feature of Islamic journalism? 
TABLE 2

Backgrounds of journalists

\begin{tabular}{|c|c|c|c|c|c|c|c|c|c|c|c|c|}
\hline & Albania & Bangladesh & Egypt & Indonesia & Kosovo & Malaysia & Oman & Qatar & Sierra Leone & Sudan & Turkey & UAE \\
\hline N & 292 & 339 & 400 & 662 & 202 & 349 & 257 & 383 & 220 & 236 & 236 & 237 \\
\hline Female $(\%)$ & 51.7 & 10.9 & 36.5 & 21.5 & 45.5 & 52.4 & 39.7 & 27.7 & 29.1 & 34.9 & 44.9 & 50.2 \\
\hline Age (mean) & 32.54 & 36.7 & 36.7 & 34.4 & 30.83 & 35.5 & 37.9 & - & 31.6 & 37.3 & 32.4 & 33.7 \\
\hline Experience (mean) & 9.36 & 11.6 & 12.0 & 8.5 & 7.51 & 9.6 & 12.6 & - & 5.8 & 11.4 & 9.3 & - \\
\hline University degree (\%) & 98.0 & 86.8 & 97.3 & 87.0 & 86.2 & 82.8 & 78.7 & 72.7 & 40.4 & 95.2 & 91.1 & 91.8 \\
\hline Specialized in journalism (\%) & 72.4 & 43.7 & 71.8 & 33.9 & 67.0 & 55.9 & 61.4 & 71.1 & 48.3 & 65.2 & 31.9 & 72.6 \\
\hline
\end{tabular}


TABLE 3

Journalistic roles (across the sample)

\begin{tabular}{|c|c|c|c|}
\hline & \multirow[b]{2}{*}{ Mean $(S D)^{a}$} & \multicolumn{2}{|c|}{$\begin{array}{c}\text { Country } \\
\text { differences }\end{array}$} \\
\hline & & $\boldsymbol{F}^{\mathbf{b}}$ & $\mathrm{Eta}^{2}$ \\
\hline Report things as they are & $4.31(0.83)$ & 60.16 & 0.153 \\
\hline Promote cultural diversity & $4.27(0.89)$ & 9.45 & 0.028 \\
\hline Educate the audience & $4.14(0.94)$ & 26.67 & 0.073 \\
\hline Be a detached observer & $4.08(0.95)$ & 78.25 & 0.195 \\
\hline Provide analysis of current affairs & $4.07(0.89)$ & 50.46 & 0.132 \\
\hline Motivate people to participate in politics & $4.05(0.97)$ & 68.63 & 0.173 \\
\hline Advocate for social change & $4.03(1.00)$ & 39.42 & 0.107 \\
\hline Support national development & $4.03(1.04)$ & 32.18 & 0.089 \\
\hline Provide news that attracts largest audience & $3.95(1.06)$ & 22.01 & 0.062 \\
\hline Influence public opinion & $3.89(1.09)$ & 36.37 & 0.100 \\
\hline Provide information people need to make political decisions & $3.73(1.11)$ & 54.65 & 0.144 \\
\hline Provide advice, orientation and direction for daily life & $3.70(1.04)$ & 36.57 & 0.100 \\
\hline Monitor and scrutinize political leaders & $3.65(1.06)$ & 70.90 & 0.178 \\
\hline Monitor and scrutinize business & $3.37(1.13)$ & 50.11 & 0.133 \\
\hline Provide entertainment and relaxation & $3.35(1.18)$ & 12.50 & 0.037 \\
\hline Let people express their views & $3.21(1.24)$ & 72.78 & 0.184 \\
\hline Set the political agenda & $3.10(1.23)$ & 32.42 & 0.092 \\
\hline Convey positive image of political leadership & $2.95(1.24)$ & 43.94 & 0.119 \\
\hline Support government policy & $2.94(1.17)$ & 75.24 & 0.188 \\
\hline Be an adversary to the government & $2.90(1.27)$ & 79.48 & 0.202 \\
\hline
\end{tabular}

${ }^{\mathrm{a}}$ Average means and standard deviations (all countries have equal weight).

${ }^{\mathrm{b}} \mathrm{F}$ values; all significant at $p<0.001$; one-way ANOVA; $\mathrm{df}=11$ (except for "Educate the audience" and "Promote cultural diversity": $d f=7$ ).

Tempting as such an interpretation might be, a comparison with other multinational studies suggests that journalists in the 12 Muslim-majority countries are not quite different from their colleagues in other parts of the world when it comes to the importance of detachment and objectivity (Hanitzsch et al. 2011; Weaver and Willnat 2012). Obviously, the valuation of impartiality, detachment, and truth-telling or objectivity does not set them apart from their peers in other countries, and it is hard if not impossible to say to what extent their preference for these values emanates from religious beliefs. The professional norms of objectivity, impartiality, and detachment have traveled across borders and seem to belong to the normative core of journalism worldwide. Through a transfer of occupational ideology from the West to the global South, they are taught in journalism schools around the world and are found in almost every journalism textbook. Furthermore, the objectivity, impartiality, and detachment norms may not always be fully enacted in practice as they may clash with other professional norms or the realities on the ground.

This is also evidenced by another commonality that we found among the journalists from most of the 12 Muslim-majority countries: a tendency toward social interventionism. Journalists in Muslim-majority countries find it important to support national development, and to advocate for social change. This tendency was particularly pronounced among journalists in Bangladesh and Indonesia, Oman and Qatar, as well as in Sierra Leone and Sudan. Turkey was interesting insofar as journalists were keen to advocate for social change but were less enthusiastic in their support of national development. Journalists in many 


\section{TABLE 4}

Journalistic roles

\begin{tabular}{|c|c|c|c|c|c|c|c|c|c|c|c|c|}
\hline & \multicolumn{2}{|c|}{ Albania } & \multicolumn{2}{|c|}{ Bangladesh } & \multicolumn{2}{|r|}{ Egypt } & \multicolumn{2}{|c|}{ Indonesia } & \multicolumn{2}{|c|}{ Kosovo } & \multicolumn{2}{|c|}{ Malaysia } \\
\hline & $\%$ & Mean (SD) & $\%$ & Mean (SD) & $\%$ & Mean (SD) & $\%$ & Mean (SD) & $\%$ & Mean (SD) & $\%$ & Mean (SD) \\
\hline Report things as they are & 98.0 & $4.57(0.57)$ & 76.8 & $4.13(1.09)$ & 85.4 & $4.36(0.80)$ & 94.1 & $4.51(0.68)$ & 98.5 & $4.83(0.47)$ & 79.3 & $4.13(0.83)$ \\
\hline Promote cultural diversity & 79.5 & $4.07(0.96)$ & 87.0 & $4.41(0.89)$ & - & - & 91.9 & $4.30(0.65)$ & 87.5 & $4.51(0.81)$ & 78.9 & $4.16(0.86)$ \\
\hline Educate the audience & 73.4 & $3.98(1.00)$ & 77.4 & $4.19(1.03)$ & - & - & 94.1 & $4.36(0.65)$ & 74.9 & $4.15(1.02)$ & 81.8 & $4.20(0.83)$ \\
\hline Be a detached observer & 90.8 & $4.31(0.80)$ & 47.9 & $3.31(1.40)$ & 92.2 & $4.65(0.67)$ & 64.0 & $3.70(1.05)$ & 94.9 & $4.67(0.68)$ & 71.5 & $3.89(0.89)$ \\
\hline Provide analysis of current affairs & 77.1 & $3.94(0.72)$ & 78.4 & $4.14(0.89)$ & 79.4 & $4.17(0.86)$ & 72.8 & $3.93(0.88)$ & 92.5 & $4.50(0.74)$ & 69.8 & $3.93(0.83)$ \\
\hline Motivate people to participate in politics & 13.0 & $2.14(1.12)$ & 42.7 & $3.09(1.36)$ & 79.9 & $4.21(0.92)$ & 60.3 & $3.59(0.96)$ & 34.0 & $2.88(1.45)$ & 38.8 & $3.17(1.08)$ \\
\hline Advocate for social change & 72.3 & $3.88(1.02)$ & 79.6 & $4.16(1.11)$ & 76.3 & $4.17(0.97)$ & 81.0 & $4.03(0.78)$ & 72.3 & $4.05(1.23)$ & 61.7 & $3.67(0.95)$ \\
\hline Support national development & 73.4 & $3.85(1.13)$ & 76.3 & $4.19(1.08)$ & 69.6 & $4.04(1.10)$ & 75.1 & $3.96(0.82)$ & 70.4 & $4.01(1.10)$ & 66.8 & $3.84(0.97)$ \\
\hline Provide news that attracts largest audience & 81.6 & $4.14(0.89)$ & 75.9 & $4.16(1.03)$ & 62.7 & $3.84(1.14)$ & 76.2 & $3.96(0.73)$ & 62.1 & $3.80(1.18)$ & 67.6 & $3.88(0.93)$ \\
\hline Influence public opinion & 77.1 & $4.02(1.00)$ & 59.3 & $3.69(1.25)$ & 78.9 & $4.19(0.95)$ & 49.5 & $3.30(1.13)$ & 74.5 & $4.04(1.19)$ & 57.5 & $3.57(1.00)$ \\
\hline $\begin{array}{l}\text { Provide information people need to make } \\
\text { political decisions }\end{array}$ & 51.7 & $3.33(1.31)$ & 60.5 & $3.74(1.16)$ & 82.7 & $4.27(0.91)$ & 70.9 & $3.81(0.80)$ & 50.5 & $3.46(1.36)$ & 64.8 & $3.75(0.97)$ \\
\hline $\begin{array}{l}\text { Provide advice, orientation and direction for } \\
\text { daily life }\end{array}$ & 55.3 & $3.50(1.07)$ & 51.0 & $3.45(1.16)$ & 66.6 & $3.90(0.96)$ & 52.3 & $3.48(0.91)$ & 62.8 & $3.76(1.16)$ & 63.7 & $3.74(0.88)$ \\
\hline Monitor and scrutinize political leaders & 36.5 & $3.02(1.19)$ & 63.2 & $3.84(1.02)$ & 74.6 & $4.05(1.00)$ & 56.0 & $3.60(0.91)$ & 63.5 & $3.75(1.19)$ & 50.3 & $3.55(0.93)$ \\
\hline Monitor and scrutinize business & 27.9 & $2.74(1.13)$ & 51.3 & $3.52(1.20)$ & 53.8 & $3.56(1.13)$ & 44.3 & $3.40(0.89)$ & 46.4 & $3.36(1.23)$ & 48.7 & $3.46(0.91)$ \\
\hline Provide entertainment and relaxation & 46.0 & $3.24(1.19)$ & 38.3 & $3.16(1.23)$ & 35.2 & $3.11(1.24)$ & 54.2 & $3.59(0.82)$ & 48.2 & $3.26(1.33)$ & 50.3 & $3.47(1.00)$ \\
\hline Let people express their views & 80.1 & $4.06(0.83)$ & 78.8 & $4.21(0.98)$ & 82.2 & $4.29(0.89)$ & 85.6 & $4.12(0.66)$ & 75.9 & $4.15(1.14)$ & 71.8 & $3.95(0.88)$ \\
\hline Set the political agenda & 19.7 & $2.28(1.20)$ & 40.2 & $3.04(1.28)$ & 56.0 & $3.60(1.10)$ & 28.3 & $2.84(1.11)$ & 38.2 & $2.92(1.40)$ & 33.2 & $2.99(1.04)$ \\
\hline Convey positive image of political leadership & 18.6 & $2.21(1.25)$ & 37.3 & $2.94(1.37)$ & 21.4 & $2.60(1.27)$ & 36.3 & $3.15(1.06)$ & 25.3 & $2.71(1.32)$ & 4.3 & $3.25(1.15)$ \\
\hline Support government policy & 9.7 & $2.06(1.07)$ & 28.7 & $2.76(1.30)$ & 22.1 & $2.61(1.30)$ & 30.4 & $3.26(0.75)$ & 13.0 & $2.20(1.17)$ & 51.7 & $3.47(1.07)$ \\
\hline Be an adversary to the government & 64.9 & $3.67(1.19)$ & 28.9 & $2.54(1.52)$ & 52.3 & $3.57(1.14)$ & 10.5 & $2.67(0.94)$ & 74.5 & $4.09(1.08)$ & 45.6 & $3.27(1.14)$ \\
\hline
\end{tabular}


Report things as they are Promote cultural diversity

Educate the audience

Be a detached observer

Provide analysis of current affairs

Advocate for social change

Support national development

Provide news that attracts largest audience

Influence public opinion

Provide information people need to make political decisions

Provide advice, orientation and direction for daily life

Monitor and scrutinize political leaders

Monitor and scrutinize business

Let people express their views

Set the political agenda

Convey positive image of political

leadership

Be an adversary to the government
Motivate people to participate in politics

Provide entertainment and relaxation

Support government policy

\begin{tabular}{|c|c|c|c|c|c|c|c|c|c|c|c|}
\hline \multicolumn{2}{|r|}{ Oman } & \multicolumn{2}{|r|}{ Qatar } & \multicolumn{2}{|c|}{ Sierra Leone } & \multicolumn{2}{|r|}{ Sudan } & \multicolumn{2}{|c|}{ Turkey } & \multicolumn{2}{|r|}{ UAE } \\
\hline$\%$ & Mean (SD) & $\%$ & Mean (SD) & $\%$ & Mean (SD) & $\%$ & Mean (SD) & $\%$ & Mean (SD) & $\%$ & Mean (SD) \\
\hline 63.4 & $3.75(1.22)$ & 54.5 & $3.51(1.23)$ & 94.9 & $4.59(0.67)$ & 90.4 & $4,57(0.76)$ & 97.9 & $4.79(0.57)$ & 71.2 & $4.04(1.05)$ \\
\hline- & - & - & - & 88.4 & $4.39(0.78)$ & - & - & 77.4 & $3.98(1.22)$ & 83.3 & 4.37 (0.95) \\
\hline- & - & - & - & 95.9 & $4.61(0.63)$ & - & - & 52.1 & $3.30(1.38)$ & 85.4 & $4.33(1.02)$ \\
\hline 89.5 & $4.23(0.83)$ & 53.2 & $3.48(1.22)$ & 68.5 & 3.89 (1.15) & 94.5 & $4.72(0.62)$ & 91.5 & $4.66(0.80)$ & 49.3 & $3.45(1.28)$ \\
\hline 71.6 & $3.90(1.04)$ & 40.4 & $3.19(1.23)$ & 91.6 & $4.43(0.76)$ & 90.4 & $4.56(0.76)$ & 88.3 & $4.31(0.83)$ & 65.0 & $3.82(1.14)$ \\
\hline 40.5 & $3.16(1.20)$ & 34.7 & $2.78(1.41)$ & 59.6 & 3.59 (1.28) & 70.5 & $4.07(1.26)$ & 34.4 & $2.91(1.32)$ & 64.7 & 3.76 (1.19) \\
\hline 76.7 & $4.03(1.01)$ & 57.1 & 3.64 (1.19) & 90.3 & $4.52(0.76)$ & 93.1 & $4.72(0.65)$ & 81.7 & $4.19(0.94)$ & 47.6 & $3.23(1.47)$ \\
\hline 76.7 & $4.04(1.14)$ & 56.6 & 3.58 (1.19) & 91.3 & $4.56(0.77)$ & 95.6 & $4.79(0.61)$ & 56.7 & $3.41(1.45)$ & 76.4 & $4.08(1.11)$ \\
\hline 69.3 & $3.93(1.11)$ & 48.2 & $3.38(1.23)$ & 72.4 & $4.01(1.29)$ & 89.1 & $4.52(0.85)$ & 63.8 & 3.65 (1.33) & 76.6 & $4.11(1.07)$ \\
\hline 66.1 & 3.75 (1.09) & 57.9 & $3.66(1.24)$ & 68.1 & 3.87 (1.13) & 91.4 & $4.64(0.72)$ & 77.7 & $4.74(1.12)$ & 70.4 & $3.85(1.23)$ \\
\hline 53.7 & $3.59(0.93)$ & 34.3 & $2.78(1.40)$ & 79.8 & $4.14(1.04)$ & 87.3 & $4.49(0.91)$ & 78.7 & 3.96 (1.09) & 42.3 & $3.42(1.45)$ \\
\hline 63.8 & $3.76(0.95)$ & 44.0 & $3.23(1.27)$ & 76.0 & $4.07(0.88)$ & 87.5 & $4.51(0.86)$ & 41.9 & $3.02(1.25)$ & 68.4 & $3.92(1.12)$ \\
\hline 33.5 & $3.30(0.88)$ & 29.7 & $2.58(1.35)$ & 79.8 & $4.17(1.05)$ & 83.7 & $4.39(0.97)$ & 86.0 & $4.14(0.92)$ & 49.3 & $3.37(1.36)$ \\
\hline 54.5 & $3.43(1.17)$ & 29.0 & $2.61(1.34)$ & 55.5 & $3.50(1.13)$ & 81.7 & $4.37(1.00)$ & 63.4 & 3.61 (1.09) & 30.5 & $2.87(1.36)$ \\
\hline 54.1 & $3.58(1.02)$ & 47.2 & $3.33(1.27)$ & 59.0 & $3.60(1.22)$ & 60.4 & $3.71(1.36)$ & 32.3 & $2.68(1.30)$ & 50.9 & $3.48(1.22)$ \\
\hline 63.4 & $3,67(1.11)$ & 36.3 & $2.90(1.40)$ & 95.4 & $4.58(0.65)$ & 90.9 & $4.59(0.88)$ & 87.2 & $4.30(1.05)$ & 38.9 & $2.97(1.46)$ \\
\hline 44.4 & 3.19 (1.08) & 36.4 & $2.93(1.37)$ & 55.5 & $3.49(1.22)$ & 53.5 & $3.58(1.41)$ & 69.6 & $3.74(1.15)$ & 29.1 & $2.63(1.45)$ \\
\hline 40.1 & $3.35(0.96)$ & 48.8 & $3.34(1.28)$ & 35.4 & 2.77 (1.38) & 34.2 & $2.83(1.55)$ & 11.8 & $2.09(1.20)$ & 75.4 & $4.14(1.08)$ \\
\hline 47.9 & $3.32(1.23)$ & 49.1 & 3.35 (1.29) & 46.2 & $3.25(1.22)$ & 34.6 & $2.92(1.54)$ & 6.5 & $1.85(1.07)$ & 78.2 & $4.24(1.03)$ \\
\hline 20.2 & $2.54(1.23)$ & 16.5 & $1.96(1.29)$ & 32.5 & $2.64(1.35)$ & 43.2 & $3.12(1.62)$ & 35.9 & $3.00(1.47)$ & 15.6 & $1.73(1.28)$ \\
\hline
\end{tabular}

"\%" indicates the percentage saying "extremely" or "very important." 
Muslim-majority countries obviously see themselves as acting in the role of an "agent of change," who drives public conversation and contributes to the improvement of society. This result corresponds to similar findings of other surveys in Muslim-dominated societies (Hanitzsch et al. 2011; Pintak 2014; Romano 2003). Nonetheless, the interventionist attitude of journalists in our sample is not distinctive to the Muslim world either. Understood in the context of "development journalism," it denominates a journalistic approach supportive of efforts to bring about economic and socio-cultural development. This has been established as a common feature of many journalistic cultures in developing and transitional countries (Edeani 1993; Ramaprasad and Kelly 2003; Ramaprasad and Rahman 2006; Romano 2003).

The journalists' interventionist attitude and participant stance clearly resonates with the idea of maslahah, which broadly means to work for the public interest. The willingness of journalists to nurture public conversation and contribute to a better society is often but not necessarily related to providing support for government policy. The emphasis on government support differs from country to country; cross-national differences explain 18.8 percent of the overall variation in the data. Supporting government policy is most pronounced in the UAE, Malaysia, Qatar, Oman, and Sierra Leone, where 78.2, 51.7, 49.1, 47.9 , and 46.2 percent, respectively, of the journalists found it "extremely" or "very important" in their work. Likewise, the idea that journalists should convey a positive image of political leadership was generally little appreciated by the journalists and found some support only among journalists in the UAE and in Qatar. Overall, such a collaborative, or facilitative, understanding of journalists' roles was least pronounced in Albania, Egypt, Kosovo, Sudan, and Turkey. Hence, an interventionist attitude among journalists coincides with supporting state authorities in some contexts, while it does not do so in others.

Another fairly consistent finding across the investigated Muslim-majority countries is that journalists in these societies are less keen to position themselves as adversaries of the government. This role was highly rated only in Albania and Kosovo, while it is less appreciated by journalists in all other countries, most notably in Indonesia and the Gulf states. These results come as no surprise. Adversarial journalism is based on the separation of the media from the state, which allows journalists to act as a countervailing force that proactively challenges power elites if needed. This assumption may not hold for many of the investigated countries. The journalists' interventionist attitude reported above suggests that rather than acting as an adversary of the government, thus creating hostility between the media and political powers, journalists see themselves as part of the political process and therefore act as a constructive force. Journalists' terms of employment also matter in the equation. In many Gulf states, journalists are-to a large extent-considered governmental employees. In these contexts, national interest or maslahah is often defined in terms that prohibit reporting that could potentially harm the national political and economic interest or national security-definitions that are far too broad to allow for critical and robust journalism (Duffy 2014). Again, Albania and Kosovo mark an important contrast here. The geographic location of these countries, in addition to differences in political systems and cultural heritage, may have propelled journalistic cultures much closer to the European mainstream.

In a similar vein, monitoring and scrutinizing political leaders and businesses were not high on the journalists' agenda compared to other roles. This marks another important difference between journalists in the studied Muslim-majority societies and their colleagues in western countries, who tend to hold the watchdog role of journalism in very high esteem (Hanitzsch et al. 2011; Weaver and Willnat 2012). However, there was quite a bit of variation 
in the extent to which this role was endorsed by journalists in the investigated countries. In fact, country differences accounted for 17.8 percent of the variance in the journalists' assessments of the importance of a monitoring politics, which is quite substantive by any standard. Monitoring and scrutinizing political leaders was found to be "extremely" or "very important" by at least three out of four journalists in Egypt, Sierra Leone, Sudan, and Turkey, while it was considerably less supported in Albania and the Gulf states.

Overall, it seems that roles that journalists carry out in the political domain are particularly vulnerable to cross-cultural variation, at least in our sample of countries. National differences accounted for large parts of the variance for the political information role ("provide information people need to make political decisions"; 14.4 percent), the political expression role ("let people express their views"; 18.4 percent), and the political mobilization role ("motivate people to participate in political activity"; 17.3 percent). Political expression was found to be particularly important by journalists in all countries but the Gulf states; political motivation-and all other political roles-were strongly embraced by journalists in Egypt.

These differences may well be related to different interpretations of the maslahah principle in the context of a given political environment and situation. Maslahah means to seek the best for the public interest, but "public interest" could refer to a variety of different things and goals. Another question is who has the authority to define the public interest. In the current political situation in Egypt, for instance, many journalists felt an urge to give a voice to the people and motivate them to actively contribute to the country's political transition. In Qatar, Oman, and the UAE, by way of contrast, there is simply no space for political contestation due to an authoritarian regime. These conditions are not likely to breed a significant "public" demand for political mobilization.

Finally, the present study found some considerable support among journalists from Muslim-majority countries concerning the importance of journalistic roles that broadly relate to the tabligh principle mentioned above. This principle embodies the pedagogic functions of journalists, through acting as educators and teachers who provide knowledge and promote a positive attitude to the community and encourage people to do good deeds. This educator role is clearly visible in our results. In all countries, with the exception of Qatar, journalists found it very important to provide analysis of current affairs. The role of educating the audience was highly rated in seven of the eight countries, where the question was asked (i.e., in Albania, Bangladesh, Indonesia, Kosovo, Malaysia, Sierra Leone, and the UAE). Here, Turkey was the exception. Comparatively less importance was attributed to the pedagogic role that relates to everyday matters ("providing advice, orientation, and direction for daily life").

At the same time, the role of promoting cultural diversity was supported in all countries where this question had been asked. The idea of acting as a mediator between different social groups is particularly relevant to countries that are inhabited by different ethnic and religious communities, such as Bangladesh, Indonesia, Kosovo, Malaysia, and Sierra Leone. Three of these countries-Indonesia, Kosovo, and Sierra Leone-have experienced serious inter-ethnic and inter-religious violence in the past, and calls for the news media to restrain from inflammatory coverage that had been publicly voiced by various social groups.

In order to visualize the similarities and differences between the 12 countries, we produced a map using the specialized software tool Visual CoPlot, ${ }^{3}$ which is based on an adaptation of multidimensional scaling. We used centered mean scores for this analysis in order 
to remove potential acquiescence bias from the data. This procedure, however, tends to emphasize differences over similarities, which we need to bear in mind when interpreting the map. On the map, commonalities and differences between countries across all included indicators are represented as spatial distances. The vectors (or arrows) represent the variables used in the analysis. Vectors for positively correlated variables point in similar directions; ${ }^{4}$ the proximity of a country to a vector indicates the extent to which journalists in this country embrace this role in their work. Overall, the mathematical properties point to a reasonable solution; the Coefficient of Alienation is smaller than 0.15 and the Average of Correlations is higher than 0.70 (Bravata et al. 2008).

Figure 1 points nicely to some meaningful country groupings. The three Gulf countries, together with Malaysia, form a cluster of countries, in which journalistic culture emphasizes a collaborative and facilitative role more than in the other countries. Oman, Qatar, and the UAE are authoritarian societies; as mentioned above, governments expect journalists to be supportive of their efforts to bring about development and stability. Bangladesh, Indonesia, and Sierra Leone form another cluster of countries in which journalists seem to be much more motivated by a monitorial approach and by their political

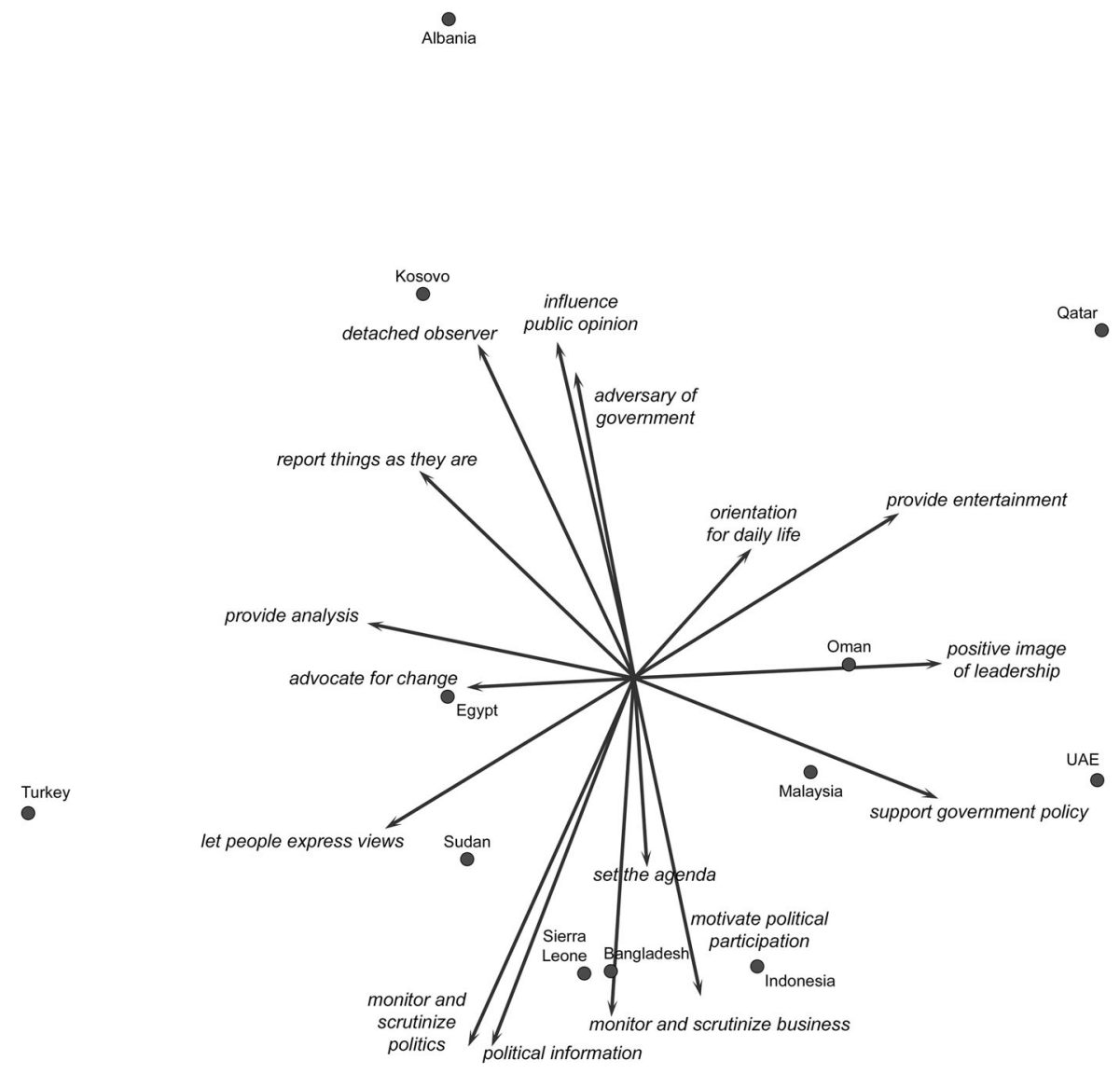

FIGURE 1

Co-plot based on centered mean scores; observations: Coefficient of Alienation $=0.109$; variables: Average of Correlations $=0.758$. 
function in society. In Egypt, Sudan, and Turkey, not far away from the former three countries, we found the most interventionist journalistic cultures. Journalists in these countries highly emphasize their role as an "agent of change" (Pintak 2014), with strong affinity to a monitorial role.

Together, the countries mentioned so far seem to cover a universe of differential understandings of the development journalism philosophy (Romano 2005, 4-8). Journalists conceive of themselves as "agents of empowerment" and as watchdogs in the countries located at the bottom and on the left side of the map. Journalists as "government partners," which can be seen as a hybrid of authoritarian and social responsibility theories, is most appreciated in the Gulf countries. Albania and Kosovo again mark an interesting contrast here. Journalistic culture in these two countries seems most "westernized" for these journalists most highly value an adversarial and detached observer approach.

\section{Conclusion}

The present analysis is the first large-scale comparative attempt to systematically study the roles of journalists in Muslim-majority countries. Based on interviews with working journalists in 12 countries, this article tries to contribute to our understanding of journalism's position in the Islamic world. We were interested in the extent to which journalists in Muslim-majority countries have similar understandings of their role in society, which could bring us closer to the identification of a distinctively "Islamic journalism." Such journalism would lead to commonalities between the investigated countries, created by unifying forces stemming from an Islamic perspective to the news media.

Based on a literature review, we identified four principles of an Islamic perspective to journalism: truth and truth-telling (siddiq and haqq), pedagogy (tabligh), seeking the best for the public interest (maslahah), and moderation (wasatiyyah). These four principles are associated with distinctive journalistic roles. For most of these roles, we found evidence in our analysis of journalists' responses from the 12 Muslim-majority countries. All above principles have their manifestations in the investigated journalistic cultures.

Moreover, we found that differences between the countries were more pronounced than similarities. One commonality was the relative importance of an interventionist approach to journalism in the investigated societies as it is embodied in the maslahah principle. Much more than in other societies, journalists conceived of themselves as change agents who steer public conversation and socio-cultural development. Notably, Albania and Kosovo escaped from this overall trend. At the same time, this interventionist attitude does not seem to resonate with the idea of adversarial and watchdog journalism. Journalists want to make an intervention in society, but they do so in a constructive fashion rather than in a confrontational and adversarial manner. In a similar vein, the tabligh principle is also pronounced among journalists in the studied countries: journalists are keen to act as pedagogues, educators, and teachers, in addition to promoting cultural diversity.

Overall, however, our analysis shows that journalists' roles in Muslim-majority countries are not so much shaped by a distinctively Islamic worldview as they were by the political, economic, and socio-cultural context in which the journalists operate. At the same time, the rather all-encompassing nature of Islamic principles, and the way these principles are differentially appropriated in the various national contexts, might well complicate such a conclusion. In the end, it may be hard to say to what extent 
journalistic culture is indirectly influenced by the appropriation of Islamic culture within a given political context, or directly by the political system itself. Furthermore, the abovementioned principles of an Islamic worldview are often differently understood and enacted across the Islamic world, within and between countries. While a basic feature of Islamic culture is the very rigid universal understanding of worship rules, a modern interpretation of Islam calls for and encourages flexible understanding an application of the above principles to make them more sensitive to real-world conditions in space and time. Future studies should bring more clarity to the professional roles of journalists across a wider range of Muslim-majority countries using a research strategy specifically tailored to the analysis of Islamic countries.

\section{ACKNOWLEDGEMENTS}

Special thanks to Dr. Mohd Safar Hasim, Universiti Kebangsaan Malaysia; Ms. Sarah Bomkampre, LMU Munich; Mahmoud M. Galander, Qatar University; Incilay Cangoz, Anadolu University; Elsayed Bekhit, Zayed University; Abdullah Al-Kindi, Sultan Qaboos University; Jonila Godole, Univesity of Tirana; Kenneth Andresen, University of Agder;

and Abit Hoxha, LMU Munich, for sharing their data for this paper.

\section{DISCLOSURE STATEMENT}

No potential conflict of interest was reported by the authors.

\section{FUNDING}

This study was made possible by the Worlds of Journalism Study, Ludwig Maximilian University of Munich; the German Research Foundation; Swiss National Science Foundation.

\section{NOTES}

1. It should be noted that the correct translation of nasihah is "advice" and not "independence" (istiqlal in Arabic).

2. More detailed methodological information can be obtained from the project website at http://worldsofjournalism.org/52/.

3. See http://davidtalby.com/vcoplot/.

4. Two indicators had to be excluded due to low correlations: "support national development" and "attract largest audience."

\section{REFERENCES}

Ahmed, Akbar S. 1992. Postmodernism and Islam: Predicament and Promise. London and New York: Routledge.

Amin, Hussein. 2002. "Freedom as A Value in Arab Media: Perceptions and Attitudes Among Journalists." Political Communication 19 (2): 125-135. doi:10.1080/10584600252907407.

Ayish, Muhammad. I. 2003. "Beyond Western-Oriented Communication Theories A Normative Arab-Islamic Perspective." Javnost - The Public 10 (2): 79-92. doi:10.1080/13183222. 2003.11008829. 
Ayish, Muhammad. 2010. "Arab State Broadcasting Systems in Transition The Promise of the Public Service Broadcasting Model." Middle East Journal of Culture and Communication 3 (1): 9-25. doi:10.1163/187398609X12584657078448.

Azzi, Abdurrahmane. 2011. "The Morality of Journalism Ethics: Readings of Al Nursi's Theory of God Attributes." Journalism Studies 12 (6): 757-767. doi:10.1080/1461670X.2011.614815.

Bravata, Dena M., Kaveh G. Shojania, Ingram Olkin, and Adi Raveh. 2008. "CoPlot: A Tool for Visualizing Multivariate Data in Medicine." Statistics in Medicine 27: 2234-2247. doi:10.1002/sim. 3078.

Carlson, Matt. 2015. "Introduction: The Many Boundaries of Journalism." In Boundaries of Journalism: Professionalism, Practices and Participation, edited by M. Carlson, and S. C. Lewis, 1-18. London, New York: Routledge.

Cohen, Bernard Cecil. 1963. The Press and Foreign Policy. Princeton, NJ: Princeton University Press. Connolly-Ahern, Colleen, and Guy J. Golan. 2007. "Press Freedom and Religion Measuring the Association Between Press Freedom and Religious Composition." Journal of Media and Religion 6: 63-76. doi:10.1080/15348420701338526.

Donsbach, Wolfgang. 2012. "Journalists' Role Perception. The International Encyclopedia of Communication". Blackwell Reference Online, accessed 14 May 2013, http://www. communicationencyclopedia.com.

Donsbach, Wolfgang, and Thomas E. Patterson. 2004. "Political News Journalists: Partisanship, Professionalism, and Political Roles in Five Countries." In Comparing Political Communication: Theories, Cases, and Challenges, edited by F. Esser, and B. Pfetsch, 251-270. New York: Cambridge University Press.

Duffy, Matt J. 2014. "Arab Media Regulations: Identifying Restraints on Freedom of the Press in the Laws of Six Arabian Peninsula Countries." Berkeley Journal of Middle Eastern \& Islamic Law 6: 1-31.

Edeani, David. 1993. "Role of Development Journalism in Nigerian Development." International Communication Gazette 52: 123-143.

El Issawi, Fatima, and Bart Cammaerts. 2015. "Shifting Journalistic Roles in Democratic Transitions: Lessons From Egypt." Journalism 17 (5): 549-566. doi:10.1177/1464884915576732.

Ferjani, Riadh. 2010. Religion and Television in the Arab World: Towards A Communication Studies Approach." Middle East Journal of Culture and Communication 3 (1): 82-100. doi:10.1163/18739860912584657078367.

Hachten, William. 1981. The World News Prism: Changing Media and Clashing Ideologies. Ames: lowa State University Press.

Hafez, Kai. 2002. "Journalism Ethics Revisited: A Comparison of Ethics Codes in Europe, North Africa, the Middle East, and Muslim Asia." Political Communication 19 (2): 225-250. doi:10.1080/10584600252907461.

Hamada, Basyouni Ibrahim. 2001. "Islamic Cultural Theory, Arab Media Performance and Public Opinion." In Public Opinion and Democracy, edited by Slavko Splichal, 215-239. Cresskill, New Jersey: Hampton Press, INC.

Hamada, Basyounin. 2004. "ICTS and Cultural Diversity with Special Reference to the Islamic Perspective." Journal of International Communication 10 (1): 34-53. doi:10.1080/13216597. 2004.9751963.

Hamada, Basyouni. I. 2008. "Satellite Television and Public Sphere in Egypt: Is There A Link?" Global Media Journal 7 (12): 1-21. http://www.globalmediajournal.com/open-access/ satellite-television-and-public-sphere-in-egypt-is-there-a-link.pdf. 
Hamada, Basyouni. I. 2016. “Towards A Global Journalism Ethics Model: an Islamic Perspective." The Journal of International Communication 22 (2): 1-21. doi:10.1080/13216597.2016. 1205506.

Hamayotsu, Kikue. 2013. “The Limits of Civil Society in Democratic Indonesia: Media Freedom and Religious Intolerance." Journal of Contemporary Asia 43 (4): 658-677. doi:10.1080/00472336. 2013.780471.

Hamdy, Naila. 2013. "Arab Investigative Journalism Practice." Journal of Arab \& Muslim Media Research 6 (1): 67-93. doi:10.1386/jammr.6.1.67_1.

Hanitzsch, Thomas, and Tim Vos. 2017. "Journalistic Roles and the Struggle Over Institutional Identity: the Discursive Constitution of Journalism." International Conference Association (ICA) conference in Fukuoka, Japan, June 9-13, 2016.

Hanitzsch, Thomas, Folker Hanusch, Claudia Mellado, M. Anikina, R. Berganza, I. Cangoz, Mihai Coman, et al. 2011. "Mapping Journalism Cultures Across Nations: A Comparative Study of 18 Countries." Journalism Studies 12: 273-293.

Janowitz, Morris P. 1975. "Professional Models in Journalism: The Gatekeeper and the Advocate." Journalism Quarterly 52: 618-626.

Kamali, Mohammad. 1998. Freedom of Expression in Islam (rev. ed.). Kuala Lumpur, Malaysia: Ilmiah Publishers Sdn.

Kaur, Kiranjit. 2000. Facilitating Asian media in promoting a culture of peace: An exploratory study on the role of Malaysian media in facilitating a culture of peace in Malaysia. Paper presented at presented at Asian media information and communication center, Selangor, Malaysia.

Kaya, Raşit, and Barış Çakmur. 2010. "Politics and the Mass Media in Turkey." Turkish Studies 11 (4): 521-537. doi:10.1080/14683849.2010.540112.

Kirat, Mohammed. 2016. "A Profile of Journalists in Qatar: Traits, Attitudes and Values." The Journal of International Communication, 1-18. doi:10.1080/13216597.2016.1175367.

Masterton, M. 2005. "Asian Journalists Seek Values Worth Preserving." Asia Pacific Media Educator 16: 41-48. Accessed September 15, 2016. http://ro.uow.edu.au/apme/vol1/iss16/6.

Mehra, Achal. 1989. Press System in ASEAN States. Singapore: Asian Media Information and Communication Centre.

Mowlana, Hamid. 1993. "The New Global Order and Cultural Ecology." Media, Culture \& Society 15 (1): 9-27.

Pintak, Lawrence. 2014. "Islam, Identity, and Professional Values: A Study of Journalists in Three Muslim-Majority Regions." Journalism 15 (4): 482-503. doi:10.1177/1464884913490269.

Pintak, Lawrence., and J. Ginges. 2008. "The Mission of Arab Journalism: Creating Change in A Time of Turmoil." International Journal of Press-Politics 13 (3): 193-227. doi:10.1177/ 1940161208317142.

Pintak, Lawrence, and S. J. Nazir. 2013. "Pakistani Journalism: at the Crossroads of Muslim Identity, National Priorities and Journalistic Culture." Media, Culture \& Society 35: 640-665. doi:10. $1177 / 0163443713483654$.

Pintak, Lawrence, and Budi Setiyono. 2011. "The Mission of Indonesian Journalism: Balancing Democracy, Development, and Islamic Values." The International Journal of Press/Politics 16 (2): 185-209. doi:10.1177/1940161210391784.

Ramaprasad, Jyotika., and J. D. Kelly. 2003. "Reporting the News From the World's Rooftop: A Survey of Nepalese Journalists." International Communication Gazette 65: 291-315. doi:10.1177/0016549203065003005. 
Ramaprasad, Jyotika, and S. Rahman. 2006. "Tradition with A Twist: A Survey of Bangladeshi Journalists." International Communication Gazette 68: 148-165. doi:10.1177/1748048506062232.

Ramli, Asep Syamsul. 2005. Jurnalistik Dakwah, Visi dan Misi Dakwah Bil Qalam. Bandung: Remaja Rosda Karya.

Romano, Angela. 2003. Politics and the Press in Indonesia. Understanding an Evolving Political Culture. New York: Routledge Curzon.

Romano, Angela. 2005. "Asian Journalism: News, Development and the Tides of Liberalization and Technology." In Journalism and Democracy in Asia, edited by Angela Romano, and Michael Bromley, 1-14. London \& New York: Routledge.

Rugh, William A. 2014. Arab Mass Media: Newspapers, Radio, and Television in Arab Politics. Westport, CT: Praeger.

Sakr, Naomi. 2006. "Foreign Support for Media Freedom Advocacy in the Arab Mediterranean: Globalization From Above or Below?" Mediterranean Politics 11 (1): 1-20. doi:10.1080/ 13629390500490361.

Schmidt, Vivien. A. 2010. "Taking Ideas and Discourse Seriously: Explaining Change Through Discursive Institutionalism as the Fourth 'new Institutionalism'." European Political Science Review 2: 1-25. doi:10.1017/S175577390999021X.

Schultz, Ida. 2007. "The Journalistic Gut Feeling: Journalistic Doxa, News Habitus and Orthodox News Values." Journalism Practice 1: 190-207. doi:10.1080/17512780701275507.

Skjerdal, Terje. S. 2012. "The Three Alternative Journalisms of Africa." International Communication Gazette 74 (7): 636-654. doi:10.1177/1748048512458559.

Steele, Janet. 2011. "Justice and Journalism: Islam and Journalistic Valuesin Indonesia and Malaysia." Journalism 12 (5): 533-549. doi:10.1177/1464884910388234.

Steele, Janet. 2013. "Trial by the Press: An Examination of Journalism, Ethics, and Islam in Indonesia and Malaysia." The International Journal of Press/Politics 18 (3): 342-359. doi:10.1177/ 1940161213484588.

Tapsell, Ross. 2013. "The Media Freedom Movemenet in Malaysia and the Electoral Authoritarian Regime." Journal of Contemporary Asia 43 (4): 613-635. doi:10.1080/00472336.2013. 765138.

Taylor, Bill. 2015. Kosovo: Setting Media Standards, Public Awareness and Effectiveness of the Independent Media Commission and the Press Council of Kosovo. UK: Thomson Foundation.

Ushama, Thameem. 2014. "Is Islam A Religion of Moderation or Extremism? : A Study of key Islamic Teachings." Asian Social Science 10 (8): 184-200. doi:10.5539/ass.v10n8p184.

Valeriani, Augusto. 2010. "Pan-Arab Satellite Television and Arab National Information Systems: Journalists' Perspectives on A Complicated Relationship." Middle East Journal of Culture and Communication 3 (1): 26-42. doi:10.1163/18739860912584657078321.

Weaver, David. H.1998. The Global Journalist: News People Around the World. Cresskill, NJ: Hampton.

Weaver, D., and Cleveland Wilhoit. 1996. The American Journalist in the 1990s: U.S. News People at the end of an era. Mahwah, NJ: Erlbaum.

Weaver, David. H., and Lars Willnat, eds. 2012. The Global Journalist in the 21st Century. New York: Routledge.

Xu, Xiaoge. 2005. Demystifying Asian Values in Journalism. Marshall Cavendish: Singapore.

Zelizer, Barbie. 1993. "Journalists as Interpretive Communities." Critical Studies in Mass Communication 10: 219-237. doi:10.1080/15295039309366865. 
Nurhaya Muchtar (author to whom correspondence should be addressed), Department of Communications Media, Indiana University of Pennsylvania, USA. E-mail: nmuchtar@ iup.edu

Basyouni Ibrahim Hamada, Department of Mass Communication, Qatar University, Qatar. E-mail: bhamada@qu.edu.qa

Thomas Hanitzsch, Department of Communication Studies and Media Research, Ludwig Maximilian University of Munich, Germany. E-mail: hanitzsch@ifkw.Imu.de

Ashraf Galal, Mass communication, Cairo University, Egypt. E-mail: A.galal@qu.edu.qa

Masduki, Department of Communication, Indonesian Islamic University, Indonesia. E-mail: masduki@hotmail.com

Mohammad Sahid Ullah, Department of Communication and Journalism, University of Chittagong, Bangladesh. E-mail: ullah_sahid@yahoo.co.uk 